\title{
Seroprevalence of Hepatitis C Virus among Prisoners in Lakan Prison, North of Iran, Is There Still a Concern?
}

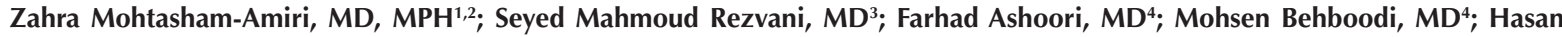 \\ Toosi, MD; ; Reza Jafari-Shakib, MD, $\mathrm{PhD}^{6,7^{*}}$ \\ ${ }^{1}$ Department of Preventive and Community Medicine, School of Medicine, Guilan University of Medical Sciences, Rasht, Iran \\ ${ }^{2}$ Guilan Road Trauma Research Center, Guilan University of Medical Sciences, Rasht, Iran \\ ${ }^{3}$ CDC Department, Guilan University of Medical Sciences, Rasht, Iran \\ ${ }^{4}$ General Physician, Health Center of Lakan Prison, Rasht, Iran \\ ${ }^{5}$ Behavioral Consultant Center, Rasht Health Center, Guilan University of Medical Sciences, Rasht, Iran \\ ${ }^{6}$ Department of Immunology, School of Medicine, Guilan University of Medical Sciences, Rasht, Iran \\ ${ }^{7}$ Medical Biotechnology Research Center, School of Paramedicine, Guilan University of Medical Sciences, Rasht, Iran
}

\begin{abstract}
Background: Hepatitis $C$ is a major cause of liver failure and liver transplantation. The known risk factors of this disease include blood transfusion, injection drug use, high risk sexual behaviors, tattoos, and use of shared blades and syringes. Due to the higher risk of viral hepatitis among people in prison, this study was done to find the seroprevalence of hepatitis $\mathrm{C}$ virus (HCV) and associated risk factors in Lakan Prison in Rasht.

Methods: Prisoners in Lakan Prison underwent a cross-sectional study in 2018. A questionnaire containing demographic information and risk factors was distributed to the inmates and they were asked complete them. High-risk individuals were selected and a blood sample was taken and tested. Data were collected and analyzed by SPSS1 8 software.

Results: Out of 2215 prisoners, 1238 people had at least one risk factor, of whom 408 individuals were selected by random sampling. One hundred inmates were positive for anti-HCV antibody, yielding a prevalence of 24.5\% (95\% Cl: $20.4 \%-28.7 \%)$ of whom $42.6 \%$ were people who injected drugs and 4 cases were found positive for the hepatitis B surface antigen, yielding a $1 \%$ prevalence $(95 \% \mathrm{Cl}, 0.2 \%-2 \%$.). A history of injecting drug use (OR 4.28, 95\% Cl: 2.55-7.17), and previous history of imprisonment (OR 2.94, 95\% Cl: 1.34-6.53) had association with HCV infection.

Conclusion: The present study shows that hepatitis $\mathrm{C}$ is prevalent in prisons and preventive and screening programs should be implemented with necessary training for inmates.

Keywords: Drug users, Hepatitis B, Hepatitis C, Prisoners, Iran

Cite this article as: Mohtasham-Amiri Z, Rezvani SM, Ashoori F, Behboodi M, Toosi H, Jafari-Shakib R. Seroprevalence of hepatitis C virus among prisoners in lakan prison, north of iran, is there still a concern?. Arch Iran Med. 2021;24(10):765-770. doi: 10.34172/ aim.2021.113
\end{abstract}

Received: June 11, 2020, Accepted: November 4, 2020, ePublished: October 1, 2021

\section{Introduction}

Chronic hepatitis $\mathrm{C}$ virus (HCV) infection is responsible for liver fibrosis, cirrhosis, and hepatocellular carcinoma and is a major cause for liver transplantation in many countries. ${ }^{1}$ According to published statistics, 71 million people lived with HCV infection in 2016 and 399000 deaths occurred due to HCV each year. Also, 1.75 million new cases of HCV occurred globally based on The World Health Organization report in 2015. The Eastern Mediterranean and European Regions with the prevalence of $2.3 \%$ and $1.5 \%$, respectively, are the more prevalent regions for $\mathrm{HCV}$ infection. ${ }^{2}$ A prevalence of viral hepatitis $\mathrm{C}$ in the general population in Iran is estimated to be $0.0 \%$ to $3.1 \%$, with a median of $0.3 \%{ }^{3}$

One of the high risk groups for blood-borne infections such as hepatitis $\mathrm{C}$ are prisoners with the rate of infection varying in different geographical areas and depending on risk behaviors. The HCV prevalence among prisoners was reported at $23.7 \%$ in the Middle East and North Africa (MENA), ${ }^{4} 18 \%$ in the United Stattes, ${ }^{5}$ and $15.1 \%$ worldwide. ${ }^{6}$

Iran has the highest population proportions of people who inject drugs (PWIDs), the highest risk population for acquiring HCV infection, in MENA. ${ }^{3}$ Two systematic reviews in 2017 and 2020 showed that HCV seroprevalence in Iran among prisoners was $28 \%$ and $24.88 \%$, respectively, ${ }^{7,8}$ with the highest rate (53\%) among PWIDs. ${ }^{7}$ In another study conducted in 2016 among prisoners in 10 provinces of Iran, including Guilan, the prevalence of HCV antibodies was $8.21 \%$ (95\% CI: 7.558.90). ${ }^{9}$ These studies indicate a gradual reduction in HCV prevalence among prisoners in Iran.

In 2016, the World Health Assembly adopted the Global Health Sector Strategy (GHSS) on viral hepatitis for the elimination of viral hepatitis as a major public health threat by $2030 .^{10,11}$ One important strategy to 
achieve this goal is diagnosis and proper treatment for chronic HBV and HCV infection. ${ }^{10}$ It seems that to reach the 2020 target of diagnosing 50\% of those infected, 107 million HBV infected people and 15 million HCV infected people should be urgently diagnosed. ${ }^{12}$ As prisoners are vulnerable to $\mathrm{HCV}$ infection, the aim of the study was to determine HCV prevalence among high-risk prisoners in Lakan Prison, the largest prison in northern Iran.

\section{Materials and Methods Study Population}

This cross-sectional study was carried out in Lakan prison in Rasht city, Guilan province from February 2019 to March 2019, where a total of 2615 prisoners served their sentences. All prisoners were aware of the aims of the study with the cooperation of the prison health center physicians and social workers. Everybody participated voluntarily. The inclusion criteria were people who were older than 18 years with imprisonment sentences longer than 6 months.

\section{Data Collection Procedure}

After interview with the prison administration and getting their agreement, in the first step, 2215 male prisoners participated in this study. The research team asked them to fill out an anonymous standard questionnaire that included demographic information, reasons for conviction, duration of imprisonment, previous incarceration, medical history, history of drug use, blood transfusion, alcohol and tobacco consumption, history of injecting drug use, tattoo, history of phlebotomy, sexual high-risk behavior, as well as history of receiving $\mathrm{HBV}$ vaccine, $\mathrm{HCV}$ screening, and methadone maintenance therapy. The questionnaires were coded. The interview was done for the illiterate people by the research team. In the second step, according to the sample size calculated based on a previous study ${ }^{13}$ and using $\mathrm{N}=\mathrm{Z1}-\alpha / 2 \mathrm{P}(1-\mathrm{P})$ / $\mathrm{d} 2,408$ inmates were selected by simple random sampling using a random numbers table for individuals with at least one risk factor in the first step. The process of individuals selection was shown in Figure 1.

After obtaining written informed consent from this group, a blood sample was taken from each of the participants in $3 \mathrm{~mL}$ sterile tubes containing gel and clot activator and was sent to the central lab of the medical faculty. Serum samples were separated after centrifugation at $2500 \mathrm{rpm}$ for $10 \mathrm{~min}$ and stored at $-20^{\circ} \mathrm{C}$ until use.

The sera were tested for the presence of anti-HCV and hepatitis B surface antigen (HBs Ag) (Dia.pro, Italy) by enzyme-linked immunosorbent assay (ELISA) according to the manufacturer's instructions.

\section{Statistical Analysis}

Data was entered and analyzed with SPSS software version 18. Descriptive statistics such as mean, standard deviation and/or percentages were used for quantitative variables. To show the association between demographic and
Total number of prisoners at the study period: 2615

\section{5}

Total prisoners enrolled in the study: 2215

\section{5}

Total number of prisoners with at least one risk factors: 1238

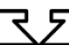

Total number of high risk prisoners who underwent HCV test: 408

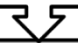

HCV positive: 100(24.6\%: 95\% CI 20.4\%- 28.7\%)

Figure 1. Flow Chart of the Recruitment of the Study and Screening Process for HCV.

behavioral variables and HCV infection, the chi-square test and Mann-Whitney test were used. To determine independent risk factors for $\mathrm{HCV}$ virus infections, logistic regression analysis was applied with forward conditional method. Risk factors with statistically significant differences on chi-square test and Mann-Whitney test entered the final model. Finally, $P$ values $<0.05$ in the study were considered statistically significant.

\section{Results}

From all 2615 inmates during the study period, 2215 prisoners (response rate $84.7 \%$ ) participated in this study with a mean age of $40.3 \pm 9.2$ years (from 19 to 76 years) and most of them were in 30-49 years age group (70.4\%). The mean length of imprisonment was $84 \pm 9.2$ months (from 6 to 480 months). Characteristics of the inmates are summarized in Table 1.

Age of onset of drug use was $21.9 \pm 6.2$ years. Inhalation was the most popular method of drug use. Heroin and crack were the most common drugs. Twenty-seven (1.21\%) mentioned a history of injecting drug use with a shared syringe. Also, 694 persons (31. 3\%) had an experience of methadone maintenance therapy, mostly more than once. Half of sexual relations were protected by condom use. Furthermore, $41.2 \%$ had tattoos; $60.8 \%$ of them had done it out of prison. A total of 1158 individuals (52.3\%) had already been screened for HCV infection. $\mathrm{HBV}$ vaccine was inoculated to 1777 participants (80.2\%) while 44 individuals $(1.99 \%)$ could not remember it. Totally, 977 individuals (44.1\%) had no risk factors for HCV infection and the others had at least one risk factor. Risk factors for HCV infection among inmates are summarized in Table 2.

In the second step, 427 prisoners with at least one risk factor for infection were selected randomly according to sample size. Nineteen of the selected prisoners did not participate in the second phase due to transfer to another prison or release. Finally, 408 inmates (95.6\%) were screened for $\mathrm{HCV}$ and $\mathrm{HBV}$. Four cases were positive for $\mathrm{HBs} \mathrm{Ag}$ (1\%, CI 95\%: $0.2 \%-2 \%)$ of whom one case had co-infection with HCV. One hundred samples were positive for anti-HCV antibody (Ab) (24.5\%, CI 95\%: $20.4 \%-28.7 \%$ ) and this rate was $42.6 \%$ among people with 
Table 1. Demographic and Criminal History of inmates

\begin{tabular}{|c|c|c|}
\hline Variables & Number & Percent \\
\hline \multicolumn{3}{|l|}{ Age group $(y)$} \\
\hline$<30$ & 244 & 11 \\
\hline $30-39$ & 813 & 36.7 \\
\hline $40-49$ & 746 & 33.7 \\
\hline $50-59$ & 269 & 12.2 \\
\hline$\geq 60$ & 74 & 3.3 \\
\hline Missing & 69 & 3.1 \\
\hline \multicolumn{3}{|l|}{ Education } \\
\hline Illiterate & 102 & 4.6 \\
\hline$\leq 5$ years & 507 & 22.9 \\
\hline $6-8$ years & 758 & 34.2 \\
\hline $9-12$ years & 560 & 25.3 \\
\hline$\geq 12$ years & 288 & 13 \\
\hline \multicolumn{3}{|l|}{ Marital status } \\
\hline Single & 661 & 29.8 \\
\hline Married & 1276 & 57.6 \\
\hline Divorced/Separated & 278 & 12.6 \\
\hline \multicolumn{3}{|l|}{ Employment } \\
\hline Self-employment & 1736 & 78.4 \\
\hline Government job & 91 & 4.1 \\
\hline Unemployment & 388 & 17.5 \\
\hline \multicolumn{3}{|l|}{ Previously incarcerated } \\
\hline No & 562 & 25.3 \\
\hline 1 time & 435 & 19.7 \\
\hline$\geq 2$ times & 582 & 26.3 \\
\hline Missing & 636 & 28.7 \\
\hline \multicolumn{3}{|l|}{ Length of incarceration $(y)$} \\
\hline$<1$ & 181 & 8.1 \\
\hline $1-5$ & 851 & 38.4 \\
\hline $6-10$ & 381 & 17.2 \\
\hline$>10$ & 802 & 36.3 \\
\hline \multicolumn{3}{|l|}{ Type of crime committed } \\
\hline Drug-related crimes & 1159 & 52.3 \\
\hline Robbery & 315 & 14.2 \\
\hline Financial crime & 213 & 9.6 \\
\hline Intentional homicide & 203 & 9.2 \\
\hline Other & 325 & 14.7 \\
\hline
\end{tabular}

a history of injecting drug use. Only 25 inmates (25\%) were aware of their infection. There was a statistically significant correlation between infection with $\mathrm{HCV}$ and drug use $(P<0.001)$, injection drug use $(P<0.001)$, ever sharing needles/syringes $(P=0.001)$, history of previous incarceration $(P<0.001)$ and having more than two risk factors $(P<0.001)$. After controlling for confounders using logistic regression, we observed a statistically significant tendency towards increasing odds of $\mathrm{HCV}$ infection by injecting drugs and previous history of imprisonment (Table 3).

\section{Discussion}

In this study, $24.5 \%$ of the high risk prisoners were infected with hepatitis $\mathrm{C}$, which is much higher than the infection in the general population $(0.3 \%) .^{3}$ It is different
Table 2. Behavioral Risk Factors for HCV Infection Among Prisoners

\begin{tabular}{|c|c|c|}
\hline Variables & Number & Percent \\
\hline \multicolumn{3}{|l|}{ Drugs use } \\
\hline Yes, no injecting & 1363 & 61.5 \\
\hline Injecting drug use & 156 & 7 \\
\hline No & 696 & 31.5 \\
\hline \multicolumn{3}{|l|}{ Blood Transfusion } \\
\hline Yes & 109 & 4.9 \\
\hline No & 2067 & 93.3 \\
\hline Unknown & 39 & 1.8 \\
\hline \multicolumn{3}{|l|}{ Hospitalization } \\
\hline Yes & 1032 & 46.6 \\
\hline No & 1162 & 52.5 \\
\hline Unknown & 21 & 0.9 \\
\hline \multicolumn{3}{|l|}{ Surgery } \\
\hline Yes & 805 & 36.3 \\
\hline No & 1393 & 62.9 \\
\hline Unknown & 17 & 0.8 \\
\hline \multicolumn{3}{|c|}{ Major Thalassemia or Hemophilia } \\
\hline Yes & 20 & 0.9 \\
\hline No & 2195 & 99.1 \\
\hline \multicolumn{3}{|l|}{ Phlebotomy } \\
\hline Yes & 353 & 15.9 \\
\hline No & 1833 & 82.8 \\
\hline Unknown & 29 & 1.3 \\
\hline \multicolumn{3}{|l|}{ Tattoos } \\
\hline Yes & 913 & 41.2 \\
\hline No & 1277 & 57.7 \\
\hline Unknown & 25 & 1.1 \\
\hline \multicolumn{3}{|l|}{ Alcohol consumption } \\
\hline Yes & 1039 & 46.9 \\
\hline No & 1131 & 51.1 \\
\hline Unknown & 45 & 2 \\
\hline \multicolumn{3}{|l|}{ Tobacco consumption } \\
\hline Yes & 1683 & 76 \\
\hline No & 532 & 24 \\
\hline \multicolumn{3}{|l|}{ Ever shared needles/syringes } \\
\hline Yes & 27 & 1.2 \\
\hline No & 2155 & 97.3 \\
\hline Unknown & 33 & 1.5 \\
\hline \multicolumn{3}{|l|}{ Sexual relationship } \\
\hline Sex with a non-spouse & 302 & 13.6 \\
\hline Sex with men & 52 & 2.4 \\
\hline No & 1861 & 84 \\
\hline \multicolumn{3}{|l|}{ Genital wounds } \\
\hline Yes & 32 & 1.4 \\
\hline No & 2138 & 96.6 \\
\hline Unknown & 45 & 2 \\
\hline
\end{tabular}

from a study conducted in 2016 in 10 provinces of Iran including Guilan which reported $8.21 \%$ prevalence in Iranian prisoners, ${ }^{9}$ closer to an earlier systematic review published from studies between 2004-2016 with 28\% prevalence, ${ }^{7}$ and lower than another systematic review in MENA in which Iran had 37.8\% anti-HCV seroprevalence among prisoners. ${ }^{4}$ Also, new studies have reported very 
diverse $\mathrm{HCV}$ seroprevalence rates among prisoners in the world (Table 4). Many factors are associated with this wide range of prevalence such as the rate of infection in the general population, access to drugs, syringes and sterile razors in prison, and laboratory test differences.

In the present study, the participants had at least one risk factor which increases the possibility of HCV. More than half of participants had a history of drug use; however, the percentage of people who inject drugs was low. The HCV seroprevalence in people who inject drugs was also lower than most studies. Implementing educational classes in prison and informing prisoners about hepatitis, as well as guiding them to methadone maintenance clinic in the prison along with high coverage of hepatitis B vaccination may account for this difference.

Only $25 \%$ of prisoners were aware of their infection. One target for elimination of hepatitis is 30\% and $90 \%$ diagnosis of HCV infection by 2020 and 2030, respectively. ${ }^{10,11}$ Unawareness of $\mathrm{HCV}$ infection is one of the problems in many infected patients, especially in developing countries due to the expense of the tests and individuals uninterested to be tested. ${ }^{26}$ Screening of high risk groups for $\mathrm{HBV}$ and $\mathrm{HCV}$ is one of the best strategies to achieve this goal. In the case of hepatitis $B$, the rate of infection was similar to the general population rate of about $1.09 \%{ }^{27}$ Considering the vast coverage of national vaccination from 1993 in Iran, ${ }^{28}$ the mean age of prisoners and receiving HBV vaccine upon entrance to prison, this finding was expected.

Like other studies, injecting drug use was an associated factor for the rate of infection. In addition, the frequency of incarceration was associated with infection prevalence, and in the present study, most of the prisoners had experienced prison more than once. It seems that the living conditions of the inmates caused them to be incarcerated repeatedly and raised the risk of infection.

Because drug distribution in prisons is not completely preventable, harm reduction by providing sterile syringes and needles has been undertaken in some prisons ${ }^{29}$ and recommended for elimination of hepatitis, ${ }^{10}$ but its effectiveness and cost-benefits needs to be studied more broadly in the future.

Although hepatitis $\mathrm{C}$ has no effective vaccine at present, co-infection with more than one viral agent exacerbates the disease; so, hepatitis B prevention programs should be implemented with vaccination of all prisoners.

Entrance screening for all inmates requires extensive research about its cost-effectiveness, but appropriate training programs need to be implemented to address the risks of blood-borne diseases, possibly with increased awareness of inmates.

The high rate of respondents in the first stage and the random selection of the second stage of sampling are reasons for the representative sample of this study.

Table 3. Affecting Factors for HCV Infection Among Prisoners

\begin{tabular}{|c|c|c|c|c|}
\hline \multirow{2}{*}{ Variables } & \multirow{2}{*}{ HCV Seronegative } & \multicolumn{3}{|c|}{ HCV Seropositive } \\
\hline & & No $(\%)$ & OR $(95 \% \mathrm{CI})$ & $P$ Value \\
\hline \multicolumn{5}{|c|}{ Previous history of imprisonment } \\
\hline No & $79(19.4)$ & $8(2)$ & 1 & 0.008 \\
\hline$\geq 1$ time & $229(56.1)$ & $92(22.5)$ & $2.94(1.34-6.53)$ & \\
\hline \multicolumn{5}{|c|}{ Injecting drug use } \\
\hline No & $238(58.3)$ & $48(11.8)$ & 1 & $<0.001$ \\
\hline Yes & $70(17.2)$ & $52(12.7)$ & $4.28(2.55-7.17)$ & \\
\hline
\end{tabular}

Adjusted variables: drug use, ever sharing needles/syringes.

Table 4. Hepatitis C infection in Previous Studies

\begin{tabular}{|c|c|c|c|}
\hline Authors & Country & Year of Publication & HCV Seroprevalence (\%) \\
\hline Azbel et $\mathrm{al}^{14}$ & Kyrgyzstan & 2016 & $49.7 \%$ of total prisoners \\
\hline Keten et $\mathrm{al}^{15}$ & Turkey & 2016 & $17.7 \%$ of total prisoners \\
\hline Puga et al ${ }^{16}$ & Central Brazil & 2017 & $2.4 \%$ of total prisoners \\
\hline Silverman-Retana et $\mathrm{al}^{17}$ & Mexico & 2017 & $3.3 \%$ of total prisoners and $43.1 \%$ of people who inject drugs \\
\hline Ibraheem et $\mathrm{al}^{18}$ & Egypt & 2018 & $16.4 \%$ of total prisoners \\
\hline Kivimets et al ${ }^{19}$ & Estonia & 2018 & $56.3 \%$ newly prisoners \\
\hline Uchechukwu et al ${ }^{20}$ & Nigeria & 2018 & $4 \%$ of male prisoners \\
\hline Moradi et $\mathrm{al}^{21}$ & Iran & 2018 & $9.48 \%$ of total prisoners \\
\hline Gahrton et $\mathrm{al}^{22}$ & Sweden & 2019 & $17 \%$ of total prisoners \\
\hline Crowley et $\mathrm{al}^{23}$ & Ireland & 2019 & $22.8 \%$ of male prisoners \\
\hline Khademi et $\mathrm{al}^{24}$ & Iran (Kermanshah) & 2019 & $22.2 \%$ of male prisoners \\
\hline Wali et $\mathrm{al}^{25}$ & Pakistan & 2020 & $10.7 \%$ of total prisoners \\
\hline
\end{tabular}


However, this study was a cross-sectional study and has all limitations of its kind; therefore, it is not clear how many prisoners were infected in prison. Another limitation of this study was missing data that may affect the results.

In conclusion, to achieve hepatitis elimination, more attention to high risk groups such as prisoners is highly recommended. Also, increasing harm-reduction coverage and HCV treatment is a priority for the health system. Further studies about HCV seroprevalence among female prisoners as well as prisoners' families are required to find the best strategy for controlling this disease.

\section{Authors' Contribution}

Developing the idea and study design: all the authors; data collection and analysis: ZMA, SMR, FA, MB, HT; performing ELISA experiments and interpretation of the results: R.J.S; drafting of the manuscript: ZMA, SMR, RJS and critical revision of the manuscript: all the authors.

\section{Conflict of Interest Disclosures}

There is no conflict of interest.

\section{Ethical Statement}

This study was approved by the ethical committee of Guilan University of Medical Sciences as IR.GUMS.REC.1397.438.

\section{Funding/Support}

This study was funded by Rasht Prisons General Administration.

\section{Acknowledgements}

We thank the Guilan Prisons General Administration for financial supporting, staff of Lakan prison health unit, Behavioral Diseases Counseling Center, especially Ms. Sheidaei and Shapour Soltankhah.

\section{References}

1. Manns MP, Buti M, Gane E, Pawlotsky JM, Razavi H, Terrault $\mathrm{N}$, et al. Hepatitis C virus infection. Nat Rev Dis Primers. 2017;3:17006. doi: 10.1038/nrdp.2017.6.

2. World Health Organization. Hepatitis C. Available from: http:// www.who.int/en/news-room/fact-sheets/detail/hepatitis-c.

3. Mahmud S, Akbarzadeh V, Abu-Raddad LJ. The epidemiology of hepatitis $C$ virus in Iran: systematic review and metaanalyses. Sci Rep. 2018;8(1):150. doi: 10.1038/s41598-01718296-9.

4. Heijnen M, Mumtaz GR, Abu-Raddad LJ. Status of HIV and hepatitis $\mathrm{C}$ virus infections among prisoners in the Middle East and North Africa: review and synthesis. J Int AIDS Soc. 2016;19(1):20873. doi: 10.7448/ias.19.1.20873.

5. Spaulding AC, Anderson EJ, Khan MA, Taborda-Vidarte CA, Phillips JA. HIV and HCV in US prisons and jails: the correctional facility as a bellwether over time for the community's infections. AIDS Rev. 2017;19(3):134-47.

6. Dolan K, Wirtz AL, Moazen B, Ndeffo-Mbah M, Galvani A, Kinner SA, et al. Global burden of HIV, viral hepatitis, and tuberculosis in prisoners and detainees. Lancet. 2016;388(10049):1089-102. doi: 10.1016/s01406736(16)30466-4.

7. Behzadifar M, Gorji HA, Rezapour A, Bragazzi NL. Prevalence of hepatitis $C$ virus infection among prisoners in Iran: a systematic review and meta-analysis. Harm Reduct J. 2018;15(1):24. doi: 10.1186/s12954-018-0231-0.

8. Najimi A, Gholami-Fesharaki M, Rowzati M. Prevalence of hepatitis $\mathrm{C}$ virus in Iranian prisoners: an updated systematic review and multilevel meta-analysis study. Hepat Mon. 2020;20(5):e102004. doi: 10.5812/hepatmon.102004.

9. Moradi G, Jafari S, Zarei B, Mahboobi M, Azimian Zavareh F, Molaeipoor $\mathrm{L}$, et al. Prevalence and risk factors for hepatitis B and hepatitis C exposure in Iranian prisoners: a national study in 2016. Hepat Mon. 2019;19(7):e91129. doi: 10.5812/ hepatmon.91129.

10. World Health Organization. Global health sector strategy on viral hepatitis 2016-2021. Available from: https://apps.who. int/iris/bitstream/handle/10665/246177/WHO-HIV-2016.06eng.f;jsessionid $=7786049$ C43803960EAF77451DA7F405F?s equence $=1$.

11. Nayagam S, Thursz M, Sicuri E, Conteh L, Wiktor S, Low-Beer $D$, et al. Requirements for global elimination of hepatitis B: a modelling study. Lancet Infect Dis. 2016;16(12):1399-408. doi: 10.1016/s1473-3099(16)30204-3.

12. Hutin YJ, Bulterys M, Hirnschall GO. How far are we from viral hepatitis elimination service coverage targets? J Int AIDS Soc. 2018;21 Suppl 2:e25050. doi: 10.1002/jia2.25050.

13. Taherkhani R, Farshadpour F. Epidemiology of hepatitis C virus in Iran. World J Gastroenterol. 2015;21(38):10790-810. doi: 10.3748/wjg.v21.i38.10790.

14. Azbel L, Polonsky M, Wegman M, Shumskaya N, Kurmanalieva A, Asanov A, et al. Intersecting epidemics of HIV, HCV, and syphilis among soon-to-be released prisoners in Kyrgyzstan: implications for prevention and treatment. Int J Drug Policy. 2016;37:9-20. doi: 10.1016/j.drugpo.2016.06.007.

15. Keten D, Emin Ova M, Sirri Keten H, Keten A, Gulderen E, Tumer S, et al. The prevalence of hepatitis B and C among prisoners in Kahramanmaras, Turkey. Jundishapur J Microbiol. 2016;9(2):e31598. doi: 10.5812/jjm.31598.

16. Puga MA, Bandeira LM, Pompilio MA, Croda J, Rezende GR, Dorisbor LF, et al. Prevalence and incidence of HCV infection among prisoners in Central Brazil. PLoS One. 2017;12(1):e0169195. doi: 10.1371/journal.pone.0169195.

17. Silverman-Retana O, Serván-Mori E, McCoy SI, Larney S, Bautista-Arredondo $S$. Hepatitis $C$ antibody prevalence among Mexico City prisoners injecting legal and illegal substances. Drug Alcohol Depend. 2017;181:140-5. doi: 10.1016/j. drugalcdep.2017.09.026.

18. Ibraheem R, Abdel- Rasoul GM, Abo Salem MA, Mourad WS. Hepatitis $B$ and $C$ viral infections among prisoners: prevalence and associated risk factors. Egypt Fam Med J. 2018;2(1):1-12. doi: 10.21608/efmj.2018.67527.

19. Kivimets K, Uusküla A, Lazarus JV, Ott K. Hepatitis C seropositivity among newly incarcerated prisoners in Estonia: data analysis of electronic health records from 2014 to 2015. BMC Infect Dis. 2018;18(1):339. doi: 10.1186/s12879-0183242-2.

20. Uchechukwu OF, Abdulrahman Y, Aliyu AU, Mustaphar U, Zama I, Charles AT, et al. Seroprevalence of HIV, HBV and HCV among prisoners in Sokoto, Nigeria. Asian J Med Health. 2018;13(3):1-8. doi: 10.9734/ajmah/2018/33128.

21. Moradi G, Gouya MM, Azimizan Zavareh F, Mohamadi Bolbanabad A, Darvishi S, Aghasadeghi MR, et al. Prevalence and risk factors for HBV and HCV in prisoners in Iran: a national bio-behavioural surveillance survey in 2015. Trop Med Int Health. 2018;23(6):641-9. doi: 10.1111/tmi.13065.

22. Gahrton C, Westman G, Lindahl K, Öhrn F, Dalgard O, Lidman C, et al. Prevalence of viremic hepatitis C, hepatitis B, and HIV infection, and vaccination status among prisoners in Stockholm County. BMC Infectious Diseases. 2019;19(1):955. doi: 10.1186/s12879-019-4581-3.

23. Crowley D, Lambert JS, Betts-Symonds G, Cullen W, Keevans M, Kelly E, et al. The seroprevalence of untreated chronic hepatitis C virus (HCV) infection and associated risk factors in male Irish prisoners: a cross-sectional study, 2017. Euro Surveill. 2019;24(14). doi: 10.2807/1560-7917. es.2019.24.14.1800369. 
24. Khademi N, Skakiba E, Khodadoust M, Khoramdad M. Seroprevalence and related risk behaviors of hepatitis C, hepatitis B and HIV infections among male prisoners in Kermanshah, Iran. Arch Iran Med. 2019;22(10):588-91.

25. Wali A, Khan D, Safdar N, Shawani Z, Fatima R, Yaqoob A, et al. Prevalence of tuberculosis, HIV/AIDS, and hepatitis; in a prison of Balochistan: a cross-sectional survey. BMC Public Health. 2019;19(1):1631. doi: 10.1186/s12889-019-8011-7.

26. Behzadifar $M$, Behzadifar $M$, Bragazzi NL. A systematic review and meta-analysis of the prevalence of hepatitis $C$ virus infection in people who inject drugs in Iran. BMC Public Health. 2020;20(1):62. doi: 10.1186/s12889-020-8175-1.

27. Rezaei N, Asadi-Lari M, Sheidaei A, Gohari K, Parsaeian M,
Khademioureh S, et al. Epidemiology of hepatitis B in Iran from 2000 to 2016: a systematic review and meta-regression analysis. Arch Iran Med. 2020;23(3):189-96.

28. Moghadami M, Dadashpour N, Mokhtari AM, Ebrahimi M, Mirahmadizadeh A. The effectiveness of the national hepatitis $B$ vaccination program 25 years after its introduction in Iran: a historical cohort study. Braz J Infect Dis. 2019;23(6):419-26. doi: 10.1016/j.bjid.2019.10.001.

29. Stark K, Bienzle U, Vonk R, Guggenmoos-Holzmann I. History of syringe sharing in prison and risk of hepatitis $B$ virus, hepatitis $C$ virus, and human immunodeficiency virus infection among injecting drug users in Berlin. Int J Epidemiol. 1997;26(6):1359-66. doi: 10.1093/ije/26.6.1359. 